\title{
Developing Problem-Based Blended Learning Model for Syntax Course in Industrial Era 4.0
}

\author{
Mulyono \\ Universitas Negeri Surabaya \\ Surabaya, Indonesia \\ mulyono@unesa.ac.id
}

\author{
Mukhzamilah \\ Universitas Negeri Surabaya \\ Surabaya, Indonesia \\ mukhzamilah@unesa.ac.id
}

\author{
Diding Wahyudin Rohaedi \\ Universitas Negeri Surabaya \\ Surabaya, Indonesia \\ didingrohaedi@unesa.ac.id
}

\begin{abstract}
In this era, there are so many developed universities that provides Communication and Information Technology Based learning. The programs can be joined via online so that there is no longer a time and space limit for its users. Therefore, the lecture services are directed at implementing CIT online in the form of elearning. In this study, the developed learning model is a blended Problem Based Learning for Syntax course. The purpose of this study is to describe the process of developing a problem-based blended learning model, the process of developing materials and teaching media, and explain the quality of the implementation of the model. This model utilizes teaching materials and media in synchronous and asynchronous encounter. The use of varied teaching materials and media is expected to improve the achievement of students' syntax competencies. The procedure focuses on (1) determination, (2) design and development, and (3) dissemination according to the development context and needs. The subjects of this study were 40 students of the Indonesian Literature S1 Study Program Class of 2018. This learning model developed through three stages, namely the planning, development and implementation stages. As a result, all components of the problem-based learning for Syntax course have been compiled in full for one semester.
\end{abstract}

Keywords-blended learning; syntax; problem-based

\section{INTRODUCTION}

For Indonesian Literature Study Program students, Syntax courses are compulsory subjects. This course examines Indonesian sentence structure by utilizing the concepts of phrases, clauses, and sentences through classroom, online, and field research activities to produce language analysis / study products and language research products to be presented in class discussions, exhibitions / majoring in majors, and used as an alternative source of further research references. That is what shows the central role of the Syntax course in language learning, especially Indonesian.

The development of a problem-based blended learning model is the first step towards online learning. Blended learning is a combination of classroom learning and online learning. The form of learning activities is a combination of synchronous and asynchronous forms. In synchronous activities, learning is carried out under the direct guidance of lecturers both in class and by utilizing information and communication technology, while in asynchronous activities, learning is carried out independently or in groups without direct guidance from lecturers. Therefore, in blended learning variations in teaching materials and learning media are needed in accordance with the competency needs to be achieved by considering the needs of students. The variation of problem-based learning materials and media is expected to be able to improve the quality of students' competency achievement.

\section{METHOD}

The development model used in this study is the Recursive, Reflective, Design, and Development (R2D2) design model. Willis and Wright [9] state that the R2D2 procedure focuses on (1) determination, (2) design and development, and (3) dissemination which is modified according to the context of the development environment and needs. These three focuses are activities carried out during the research and development process. The implementation of each of these activities is not always linear, but circular. The focus of the determination took place at the analysis stage, the focus of the design took place at the planning stage, the focus of the development took place at the development stage, and the focus of dissemination took place at the stage of disseminating the results of product development that had been prepared. 


\section{RESULT AND DISCUSSION}

The use of information and communication technologybased media in online learning has a positive impact on the learning process. The results of Bedrule-Grigoruta and Rusua's (2014) research show that the use of the internet, cell phones, social media, and the application of the latest information system enables two-way communication to take place better and more effectively. The results of Sasmito's [7] research that utilized Facebook as a learning medium also showed the same thing. However, the application of information and communication technology-based media must pay attention to the aspects of clarity of objectives, appropriate rules, techniques and mechanisms that are in accordance with user needs. It is quite instrumental in increasing satisfaction, motivation, and conformity to the needs of students [6]. The above studies show that variations in the use of media and teaching materials on online learning must be carried out to optimize learning outcomes of each individual user.

The results of Asteria's and Mulyono [3] research also showed that, in addition to variations in the material and learning media, the readiness of supporting infrastructure for online-based learning activities such as network bandwidth requirements, network speed, network connectivity consistency, database capacity, completeness and feature compatibility the interface with learning needs must also be carefully considered so that it does not hamper the implementation of online learning.

In this study the presentation of the main components of the subject of learning are developed based on Problem Based Learning (PBL). PBL is a model that challenges students as students to learn to learn, work together in groups to find solutions to real problems. Problems are used to link curiosity and analytical skills and initiative on lecture material. PBL prepares students to think critically and analytically, look for and use appropriate learning material / sources [8]. With PBL, students are faced with practical problems as a foothold in learning or in other words students learn through problems [5]. Students are required to solve problems with the knowledge and abilities they have.

This research was carried out in several stages, namely: analysis, planning, development, and evaluation.

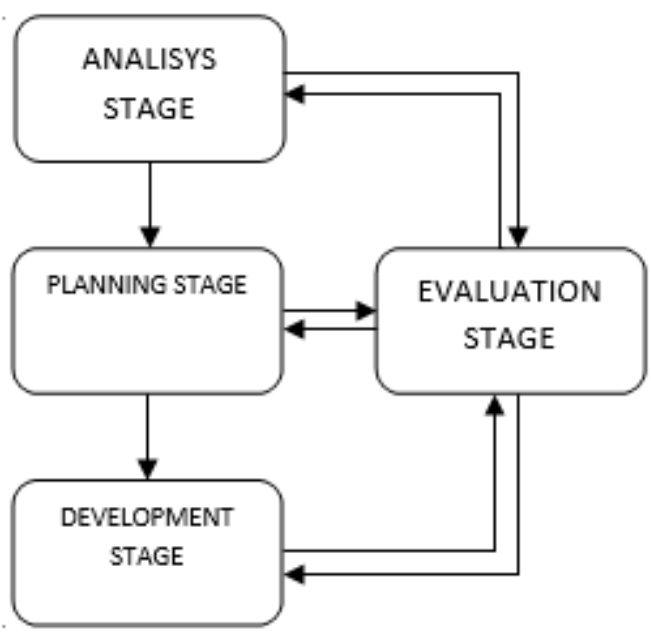

Fig. 1: Research Stages

Table 1: Blended-Syntax Course Storyline

\begin{tabular}{|c|c|c|c|c|}
\hline \multicolumn{5}{|c|}{ Storyline Modul 1 : Learning Video } \\
\hline $\begin{array}{l}\text { Mate } \\
\text { rials }\end{array}$ & $\begin{array}{l}\text { Learning } \\
\text { Outcome }\end{array}$ & Storyline & $\begin{array}{c}\text { Communic } \\
\text { ation } \\
\text { Kinds }\end{array}$ & $\begin{array}{c}\text { Evaluati } \\
\text { on }\end{array}$ \\
\hline $\begin{array}{l}\text { Syntax } \\
\text { scope }\end{array}$ & $\begin{array}{l}\text { Students } \\
\text { are able to } \\
\text { understan } \\
\text { d the } \\
\text { gcope and } \\
\text { units of } \\
\text { language } \\
\text { in the } \\
\text { field of } \\
\text { syntax| }\end{array}$ & $\begin{array}{l}\text { 1. 1. An animated character } \\
\text { introduces himself and } \\
\text { presents two illustrative } \\
\text { shows about the scope of } \\
\text { syntax } \\
\text { 2. .2. The narrator invites } \\
\text { students to review both } \\
\text { shows and conclude the } \\
\text { scope of the syntax. } \\
\text { 3. 3. Narrator shows with } \\
\text { pictures about the object of } \\
\text { syntactic research } \\
\text { 4. .4. The narrator displays an } \\
\text { animated picture of the } \\
\text { profile of Indonesian } \\
\text { literary graduates and agks } \\
\text { students to mention the } \\
\text { competencies that the } \\
\text { profile must possess. } \\
\text { 5. 5. Further explanation } \\
\text { shows the importance of } \\
\text { learning gyntax as an } \\
\text { important competency of } \\
\text { professional candidates } \\
\text { who are profiled. }\end{array}$ & $\begin{array}{l}\text { Sound- } \\
\text { equipped } \\
\text { presentation, } \\
\text { video, } \\
\text { website link, } \\
\text { journal link }\end{array}$ & $\begin{array}{l}\text { Mind } \\
\text { map }\end{array}$ \\
\hline
\end{tabular}




\begin{tabular}{|c|c|c|c|c|c|}
\hline $\begin{array}{l}\text { The } \\
\text { concepts } \\
\text { and } \\
\text { functions } \\
\text { of } \\
\text { language } \\
\text { umits in } \\
\text { the word } \\
\text { syntax } \\
\text { feld }\end{array}$ & 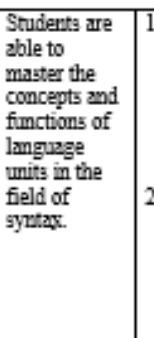 & $\begin{array}{l}\text { 1. The narnator } \\
\text { presents a } \\
\text { stopmotion about } \\
\text { the concepts and } \\
\text { functions of one } \\
\text { language in the field } \\
\text { of syntar } \\
\text { 2. The Narator } \\
\text { presents a series of } \\
\text { animated inages } \\
\text { about the gcope and } \\
\text { units of language in } \\
\text { the field of syrtas }\end{array}$ & \multicolumn{2}{|c|}{$\begin{array}{l}\text { Sound-equipped } \\
\text { presentation, } \\
\text { Tutorial video }\end{array}$} & Describing test \\
\hline \multicolumn{6}{|c|}{ Storyline Modial 2 : Dialog-Based Lsaming Video } \\
\hline $\begin{array}{c}\text { Material } \\
5\end{array}$ & $\begin{array}{l}\text { Learuing } \\
\text { Outcome }\end{array}$ & Storyline & & $\begin{array}{c}\text { Commin } \\
\text { nication } \\
\text { Kinds }\end{array}$ & Evaluation \\
\hline $\begin{array}{l}\text { Sertence } \\
\text { analysis } \\
\text { based on } \\
\text { the } \\
\text { structure } \\
\text { of its } \\
\text { constitue } \\
\text { nts }\end{array}$ & 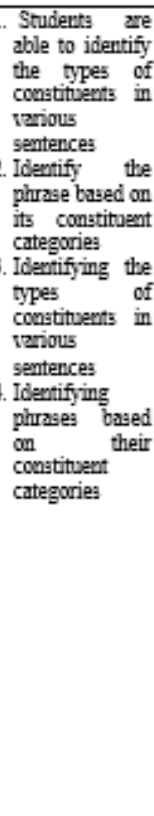 & 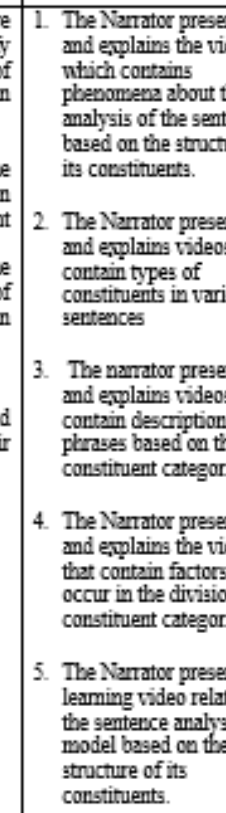 & $\begin{array}{l}\text { ats } \\
\text { beo } \\
\text { be } \\
\text { ence } \\
\text { re of } \\
\text { ats } \\
\text { that } \\
\text { ous } \\
\text { ats } \\
\text { that } \\
\text { of } \\
\text { eir } \\
\text { les. } \\
\text { ats } \\
\text { deos } \\
\text { that } \\
\text { nof } \\
\text { ies } \\
\text { ats a } \\
\text { ed to } \\
\text { is }\end{array}$ & $\begin{array}{l}\text { Sound- } \\
\text { equipped } \\
\text { presentati } \\
\text { on, } \\
\text { Tutorial } \\
\text { video }\end{array}$ & $\begin{array}{l}10 \text { guestions of } \\
\text { Subjective test }\end{array}$ \\
\hline
\end{tabular}

Operationally, problem-based syntactic blended lectures are based on the variety of learning methods or learning activities presented. The learning methods applied are learning methods or learning activities of Direct Synchronous, Virtual Synchronous, Asynchronous Mandiri, and Collaborative Asynchronous. Synchronous and asynchronous learning methods are based on the learning time between the instructor and the learner. Synchronous means learning time together, while asynchronous means time is not the same. The term Direct in this case means that learning takes place face to face, whereas Maya means learning takes place without face to face; Independent means to be done individually, whereas Collaborative means to be done in groups or by working together with other individuals other than the subjects of the course.

The application of Direct Synchronous learning methods or activities is based on the following procedure.

\begin{tabular}{|c|c|c|}
\hline Activity & Leaming Activity & Duration \\
\hline Opening & $\begin{array}{l}\text { Opening } \\
\text { - Introduction to the syllabus, } \\
\text { leaning activity, and evaluation } \\
\text { system } \\
\text { - Discussion on the learning } \\
\text { outcomes } \\
\text { - Lecturer explain the learning } \\
\text { steps }\end{array}$ & $15^{1}$ \\
\hline Core & $\begin{array}{l}\text { - Lecturers make material } \\
\text { presentations } \\
\text { - Students discuss materials } \\
\text { - Lecturers provide applied } \\
\text { exsamples of material in real life } \\
\text { in the form of stories or videos or } \\
\text { case studies } \\
\text { - Lecturers raise critical thoughts } \\
\text { to provoke student responses in } \\
\text { the form of gtatemeng or } \\
\text { questions. } \\
\text { - Students provide answers, } \\
\text { reasons, and rationale } \\
\text { - Lecturers facilitate discussion, } \\
\text { brainstorm, or question and } \\
\text { answer, and Facebook groups or } \\
\text { WhatsApp groups for this course } \\
\text { Students form discussion groups, }\end{array}$ & 120 , \\
\hline $\begin{array}{c}\text { Finigh } \\
\text { Follow up }\end{array}$ & $\begin{array}{l}\text { - Students discuss to determine the } \\
\text { conclusions of this meeting } \\
\text { - Lecturers carry out evaluation of } \\
\text { meeting } \\
\text { - The lecturer presents the } \\
\text { preparations of the next material } \\
\text { - Cloging }\end{array}$ & $15^{1}$ \\
\hline
\end{tabular}

Table 2 below shows the application of Maya Sincron method.

Table 2: Maya Sincron Method

\begin{tabular}{|c|c|}
\hline $\begin{array}{c}\text { Interactional } \\
\text { Media }\end{array}$ & Note \\
\hline Brief Explanation & $\begin{array}{l}\text { - Opening } \\
\text { - Course outline } \\
\text { - Course outline } \\
\text { - Evaluational method } \\
\text { - Syllabus } \\
\text { - Reference }\end{array}$ \\
\hline Instructional & $\begin{array}{l}\text { - Instruction to atch the video, } \\
\text { presentation and leading to the } \\
\text { linked-related material }\end{array}$ \\
\hline Digital Media & $\begin{array}{ll}\text { - } & \text { Video } \\
\text { - } & \text { Presentation } \\
\text { - Related link to the video }\end{array}$ \\
\hline Test & $\begin{array}{l}\text { - Students do the test } \\
\text { - Students check the test result } \\
\text { - Students revise their } \\
\text { competence based on the test } \\
\text { result }\end{array}$ \\
\hline $\begin{array}{c}\text { Group } \\
\text { Assignment }\end{array}$ & $\begin{array}{l}\text { - Doing the group assignment } \\
\text { - Every group submit the } \\
\text { assignment result on a } \\
\text { presentation/paper form. }\end{array}$ \\
\hline
\end{tabular}




\begin{tabular}{|c|c|}
\hline $\begin{array}{l}\text { Social Media } \\
\text { Group }\end{array}$ & $\begin{array}{l}\text { - Lecturer decides the time and } \\
\text { rules for Maya Sincronize (MS) } \\
\text { in a form of social media like } \\
\text { Facebook, Whatsaap, etc. } \\
\text { - Lecturer and students do the } \\
\text { MS using social media group } \\
\text { - Discussion } \\
\text { - Students bring the main issues } \\
\text { related to the material in the } \\
\text { group discussion forum } \\
\text { - Lecturer immediately clarifies } \\
\text { during discussions on social } \\
\text { media if they find a } \\
\text { misunderstanding } \\
\text { - Students record the results of } \\
\text { the discussion } \\
\text { - Students check and reect the } \\
\text { results of discussions based on } \\
\text { references } \\
\text { - Students draw conclusions and } \\
\text { are taken to discussion forums } \\
\text { - Each group of students } \\
\text { compiles the minutes of the } \\
\text { discussion } \\
\text { - Each group sends the minutes } \\
\text { to the lecturer email } \\
\text { The lecturer checks the } \\
\text { evaluation of the quiz results } \\
\text { and minutes of group } \\
\text { discussions }\end{array}$ \\
\hline
\end{tabular}

Those components of the problem-based learning for blended syntax course have been compiled completely for one semester study period. This course design can be viewed in the Vi-learn system.

\section{CONCLUSION}

Problem-based learning for blended syntax course is developed in several stages, both at the design stage and at the implementation stage, namely the needs analysis and framework analysis phase, the design phase, the development stage, and the implementation phase. Based on the assessment, it can be stated that the components of the blended Syntax course have complete details of the material structure for one semester. Complete course completion. Each subject does not only contain information about indicators, but also contains information / brief descriptions of the subjects / sub-subjects. For each subject, links to various other sources have been provided. The language use is quite communicative. The use of various learning objects (text, images, audio, animation, simulation) is also in accordance with needs. A variety of learning objects have been adequately provided for all subjects. Clear visual display, easy to read text, graphics and chat are labeled adequate and free of visual disturbances.

\section{REFERENCES}

[1] Valiathan, P. (2002). Blended Learning Models. Learning Circuits. ASTD

[2] Kuntarto, E. (2017). Keefektifan Model Pembelajaran Daring Dalam Perkuliahan Bahasa Indonesia Di Perguruan Tinggi. Journal Indonesian Language Education and Literature, 3(1), 99-110. Retrieved from http://www.syekhnurjati.ac.id/jurnal/index.php/jeill/\%0APEMBELAJA RAN

[3] Mulyono, M., Artawa, K., \& Asteria, P. (2018). Syntactic Simplicity in Dyslexic Children's Utterances. Atlantis Press, 108(SoSHEC 2017), 268272. http://doi.org/10.2991/soshec-17.2018.54

[4] Bedrule-Grigoruta, M. V., \& Rusua, M. L. 2014. Considerations about ELearning Tools for Adult Education. Procedia - Social and Behavioral Sciences, 142, 749-754

[5] Made, Wena. 2011. Strategi Pembelajaran Inovatif Kontemporer, Jakarta: Bumi Aksara.

[6] Marko Urh, dkk. 2015. The model for introduction of gamification into elearning in higher education. Procedia - Social and Behavioral Sciences, 197, 388-397.

[7] Sasmito, M. 2015. Pemanfaatan Media Sosial Facebook untuk Media Pembelajaran Bahasa Indonesia. Jurnal Metafora vol. 1 no. 2 Tahun 2015

[8] Sudarman. 2007. Problem Based Learning: Suatu Model Pembelajaran untuk Mengem-bangkan dan Meningkatkan Kemampuan Memecahkan Masalah.Jurnal Pendidikan Inovatif Vol. 02 No. 02 Hlm. 68-73, 2007, (online).http://physicsmaster.orgfree.com/Artikel\%20\&\%20Jurnal/Waw asan\%20Pendidikan/PBL\%20Model.pdf (Retrieved on February 11, 2017)

[9] Willis \& Wright. 2000. A General Set of Procedures for Constructivis Instructional Design: The New R2D2 Model. Educational Technology 40: $5-20$.

[10] Retrieved from: https://vi-learn.unesa.ac.id/course/. 